\title{
Georadar surveys of the flooring in the St. Francis of Assisi basilica in Krakow
}

\author{
Monika Łyczak ${ }^{1}$, Jacek Adamiec ${ }^{2}$, Tomasz Skupień², Tomasz Małysa², \\ Anna Groffik ${ }^{3}$ \\ ${ }^{1}$ Firma Archeologiczna FRAMEA - Monika Łyczak; ul. Na Kozłówce 4a/10, 30-664 Krakow, Poland; \\ e-mail: archeologia@framea.pl \\ ${ }^{2}$ GPR24.COM.PL; Roztoka 1,05-084 Leszno, Poland; e-mail: info@gpr24.com.pl \\ ${ }^{3}$ GEO-RADAR; Wilczyce, ul. Malinowa 2c, 51-361 Wrocław, Poland; e-mail: info@gpr.pl
}

(C) 2018 Authors. This is an open access publication, which can be used, distributed and reproduced in any medium according to the Creative Commons CC-BY 4.0 License requiring that the original work has been properly cited

Received: 17 January 2018; accepted: 26 September 2018; first published online:

\begin{abstract}
Basilica of St. Francisco of Assisi together with the buildings of the Franciscan convent constitute one of the most important points on the map of medieval Krakow. However, their architectural transformations are still not well recognized. In 2015, the opportunity to expand this knowledge occured. Within the basilica itself, along with the adjacent chapels, a comprehensive, non-invasive, georadar floor examination was held. Its effect, apart from confirming the location of known tombs and burial crypts, was the discovery of completely unknown underground rooms. Using small-hole drills, the rooms were recognized as burial crypts. Currently, their diagnosis is conducted by archaeological methods. The presented case study was also an occasion to describe explicitly the methodological bases of crypt identification practice, using connection between some specific construction details characteristic for ancient European architecture and the corresponding GPR manifestations (diagnostic features).
\end{abstract}

Keywords: medieval Krakow, burial crypts, georadar surveys, non-invasive research methods, tanatology

\section{INTRODUCTION}

The monastery complex of the Franciscan Order in Krakow together with St. Francis Church was constructed inside a well-developed proto-town, located on the north foreground of the ducal suburb called Okol (Fig. 1) (Łyczak et al., in print, Niewalda \& Krasnowolski 1981, Niewalda 2004). The Franciscan friars brought from Prague around 1237, were given a stone built-up lot, earlier owned by the Gryfit family or Krakow Chapter - capitulum (perhaps at first friars had only the right to use, not ownership of the property) (Wyrozumski 1992). Hitherto, two of the oldest, pre-franciscan buildings have recently been found due to the archeological survey; among them a Romanesque building made of rectangular limestone blocks (cubes; latter reused to build the monastery buildings) and a gothic defensive building used by monks in the initial period of functioning of the monastery (Szyma 2005, Zaitz 2005, 2014, Niewalda \& Rojkowska 2006). The complete size and purpose of the buildings taken over by the friars is still unknown. It is speculated they could be parts of curia - defensive residence of Krakow voivode Teodor (Czader) Gryfita and/or a chapel connected with it. It is also unknown whether these were the only stonebuilt buildings existing in this region in the first half of the $13^{\text {th }}$ century.

Undoubtedly, the area placed at Franciscan friars disposal has undergone intensive urban transformations for the last 800 hundred years. In the 
early period of the urban complex existence the transformations were primarily associated with the development of the town suburb as well as the later Great Charter of Krakow and its spatial transformations, with the gradual liquidation of fortifications (including the moat) of the Okol as a most important factor. Initially the Franciscan lot was much smaller, strictly limited by surrounding fortifications. Therefore the area currently occupied by patio concentrated monastery buildings was built gradually, beginning from half of the $13^{\text {th }}$ century to first half of the $15^{\text {th }}$ century, together with growing ground accessibility after the diminish of the moat. The chronology of the stages of the monastery complex development is well known due to a large amount of archeological and architectural research as well as field supervisions carried out recently along with maintenance and investments works in monastery (Fig. 2) (Zaitz 2005, 2006, Niewalda 2006, Łyczak 2016).

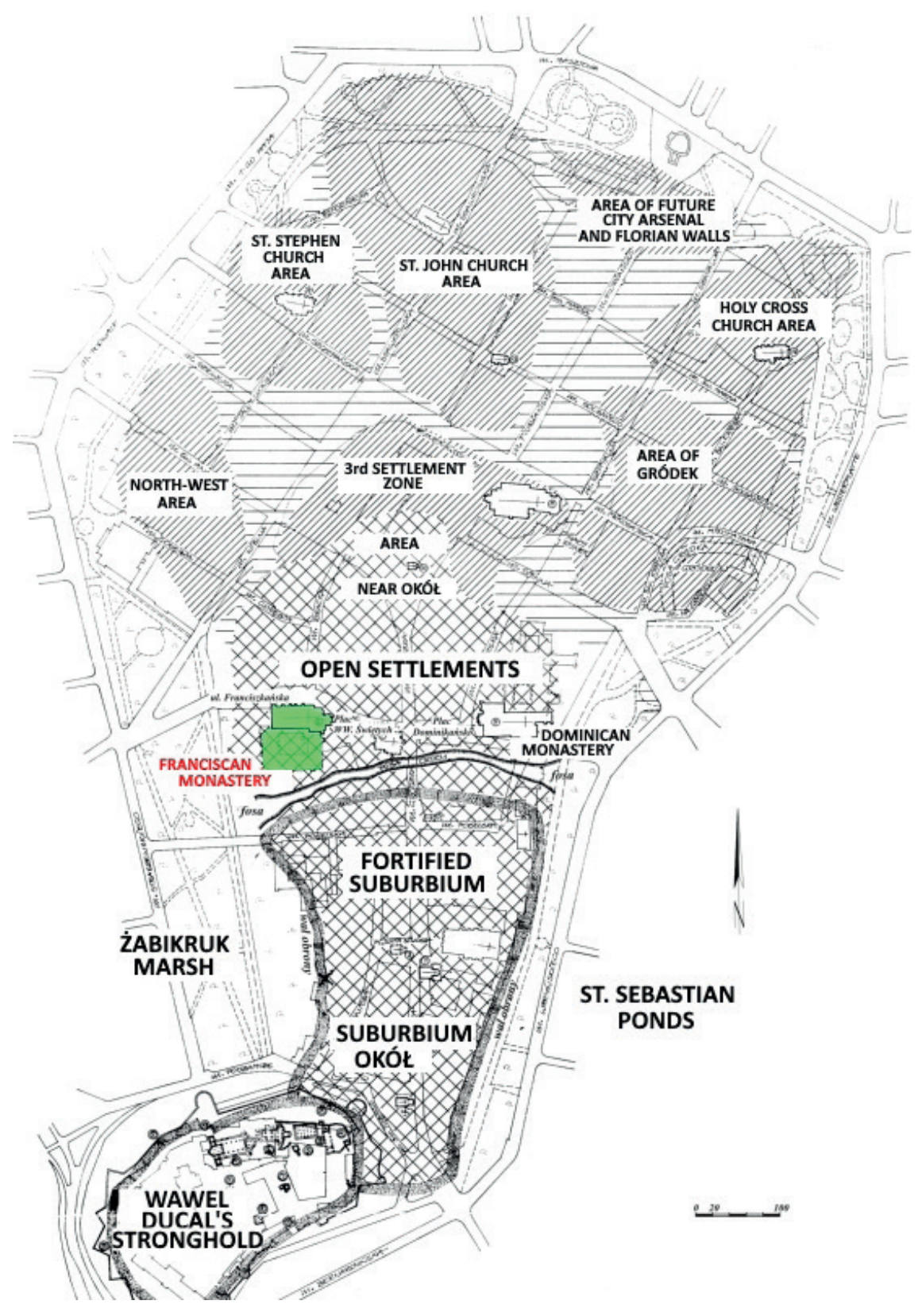

Fig. 1. Krakow, Monastery of the Franciscan Order, early middle ages settlement in the times before town location in 1257 (developed by E. Zeitz and M. Zaitz, after: Radwański 1975) 


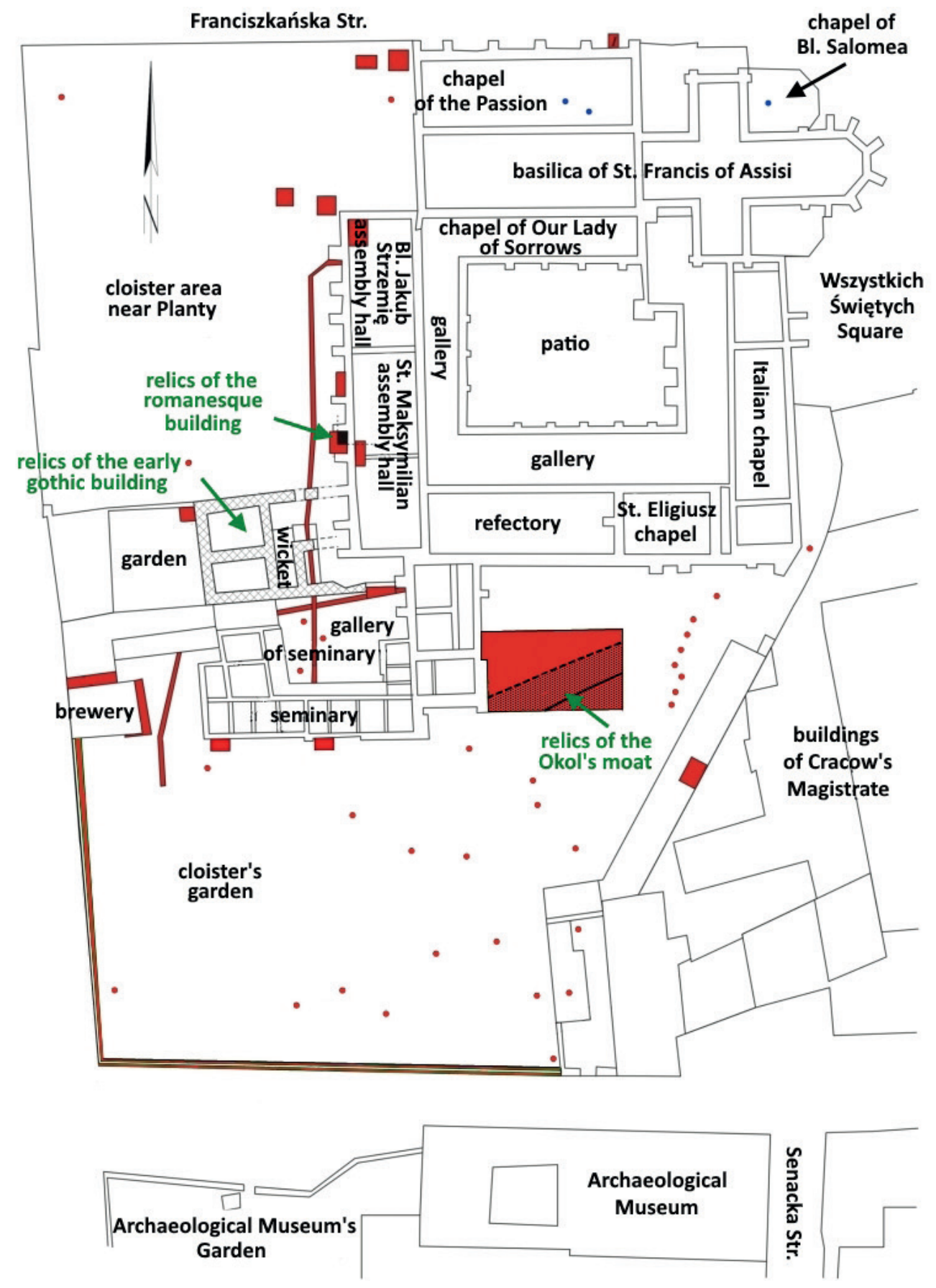

Fig. 2. Krakow, Monastery of the Franciscan Order; location of archeological drillings and trenches on the monastery's sketch, red colour - archival archeological, constructional and installation trenches, and geotechnical drillings, blue colour - small diameter drillings made in 2015 (developed by E. Zaitz, M. Zaitz, M. Łyczak)

There is opposite case with the ground occupied by the sanctuary. Some church blazes $(1462,1476,1655$ and 1850) damaged not only the parts of liturgical equipment but also caused serious damage to the brick-build elements. Major reconstructions carried out due to the fire damage (mostly historicizing renovation of the basilica in the second half of the $19^{\text {th }}$ century) make it difficult to recognize the chronological stages of the building development. It is more impeded by the 
abundant polychromy (it is impossible to make an architectural outcrop on the walls) together with lack of archaeological research inside the church. For these reasons, architecture researchers are still arguing about the shape of the original temple, suggesting among others theses: the priority of the so-called old sacristy as a religious oratory, the erection of the oldest church in the form of a Greek cross (with the character of, for example, a memorium or martyrium) or a rectangular presbytery extended further by two annexes. Furthermore it is not clear where the church's tower was located and whether the naval foundation walls was initially asymmetric or the two naves were originally even (Bochnak \& Samek 1971, Skibiński 1977, Włodarek \& Węcławowicz 2006, Kęder \& Komorowski 2007, Niewalda \& Rojkowska 2008, Walczak 2015) .

\section{THE PURPOSE OF THE SURVEYS}

A perfect opportunity to broaden knowledge about the historical development of the basilica's interior appeared in 2015 (Eyczak 2015). In connection with the assembly of underfloor heating installation inside the church of St. Francis of Assisi, ground penetrating georadar (GPR) surveys were also planned and then carried out. Georadar survey is one of the geophysical research methods. This method enables non-invasive (NDT - Non Destructive Testing) recognition of the medium's structure, its parameters and anomalies occurring in it, in a continuous, economic and fast way. GPR data analysis in the interior of the basilica were aimed at identifying possible relics of old architecture which presence could affect the completion of the investment project, or which could be accidentally damaged at the stage of project implementation.

GPR prospection was made using the Ground Explorer georadar (GX) of the Swedish company MALA equipped with an antenna with a center frequency of $450 \mathrm{MHz}$, working in modern HDR (High Dynamic Range) technology and VIY-300 ground penetrating radar (GPR) with frequency $300 \mathrm{MHz}$ made by Transient Technologies, cooperating with the built-in Synchro3 software.

Archaeological supervising during the scanning was aimed at on-going verification of research results in the context of searching for possible architectural remains, i.e. buildings older than existing church, underground elements of the earlier division of the nave or the original western closure-walls of the church. The registration of newly discovered and verification of known (based on the existing archival plan) underground rooms (spaces) identified during the measurements was carried out up to date. The research supervision was also carried out during drilling small diameter holes. This verified the presence of crypts suggested as a result of GPR results interpretations.

The area of main nave of the basilica, presbytery, transept and chapels of Our Lady of Sorrows and Blessed Salomea (except for the fragments occupied by church equipment: benches, confessionals, platforms for the altars, etc.), and almost the entire space of the Chapel of the Passion (available thank to the temporary lack of the equipment related to the ongoing renovation) were largely covered with the georadar survey profiles.

\section{SURVEY METHODOLOGY}

The georadar method applied during the reconnaissance belongs to the group of geophysical radiofrequency methods. GPR (Ground Penetrating Radar) measurement instrument consists of a central unit and a shielded monostic antenna system (combined transmitting and receiving antenna). The GPR antenna transmits electromagnetic energy in the form of radio frequency waves in order to identify the ground structure and anthropogenic constructions. It does this without interfering with their mechanical cohesion. Therefore this method belongs to the type of nondestructive testing, which is why it can be successfully used during research in historic buildings (Karczewski 2007).

As mentioned above, the tests were performed using the standard reflective profiling technique with no significant transmitter-receiver offset. In this situation, the fixed antenna system moves along the profile, and the transmitting antenna emits electromagnetic pulses at a specific distance interval along the profile. Electromagnetic pulses propagate inside the ground and the receiving antenna - moving along the survey profile together with the transmitting antenna, records reflected 
signals. These reflections are recorded on a laptop or dedicated recorder. The recorded data are presented as the echograms. The vertical axis of the echogram corresponds to the time scale of the recorded pulse in nanoseconds [ns], and the horizontal axis in turn corresponds to the number of the single measurement point expressed in the distance scale, e.g. the distance along the measurement profile (in meters). During the data processing, an approximate conversion of the vertical time travels into a depths is made.

A necessary condition for observing a useful signal carrying information about the structure is the contrast of the relative dielectric constant between the medium (i.e. ground) and the object sought. In the case of the location of anthropogenic objects, such as walls, tunnels, graves, old trenches, etc., there are usually significant material contrasts well expressed in the differences of the dielectric constant. If the object sought (i.e. crypt) is filled with the air (relative dielectric constant close to 1), there is a significant contrast to the rocks that build the tested ground (dielectric constant from several to several dozens), so that the object's scattering response should clearly and significantly differ from the background at the echogram obtained on the survey profile running over this object.

The depth range of the GPR method is a resultant of the frequency of the emitted signal, the attenuation coefficient and medium-scale granulation of the investigeted material, and it depends on the mentioned contrast and size of the examined objects. The higher frequency is used, the depth range decreases, while the vertical resolution increases.

\section{RECORDING DATA, DATA PROCESSING, STRUCTURAL INTERPRETATION AND VISUALIZATION}

3D Survey was carried out using the georadar MalaGX with an impulse antenna with a center frequency of $450 \mathrm{MHz}$. The entire area of the Franciscan Basilica including chapels was covered with the profiles. They were set up at a distance of less than $50 \mathrm{~cm}$ from each other (excluding the
Chapel of the Passion, where transversal profiles were set up every $2 \mathrm{~m}$ for technical reasons) (Fig. 3).

The analysis of the EM wave propagation velocity in the medium was made on the basis of fitting of the model hyperbole to the observed diffraction hyperbole (Conyers 2004, Jol 2009). Due to the small depth of the occurrence of the detected crypts' and tunnels' ceilings, the near-surface medium was not separated into thinner layers. The area under consideration was divided into two parts, inside which the dielectric constant changes were small and the appropriate average value was used in each of these parts (Chapel of the Passion - value of the relative dielectric constant 9.2, the rest of the basilica - value 7.1).

The recorded data has been processed using Geo-radar software called SUBVIEW. Filtration applied:

- "Bandpass" - mid-pass filtering (vertical) along scans was used in order to get rid of high frequency (noise).

- "Maximum phase correction" - reconciliation of signal time positions in the "registration window" between scans in order to remove mutual time shifts of individual runs.

- "Start time shift" - to shift the time surface response (previously agreed between runs) to time zero.

- "Time cut" - to omit the visualization of data about too high return times, which did not carry any significant information about the structure of the medium.

- "Hi pass" - high-pass filtering along the distance to remove coherent signals ("Background Removal").

- "FK Migration 2D" - for reduction of diffraction hyperbole and correction of position and inclination of flat reflections.

- Integration of profile data into a complete and consistent set for 3D visualization with absolute amplitude values for spatial and temporal synchronization. These results were interpolated using krigging and appropriately selected variograms.

The final data was visualized by successive horizontal slices (every $8 \mathrm{~cm}$ below floor level starting at depth $0 \mathrm{~cm}$ ) (Fig. 4). 


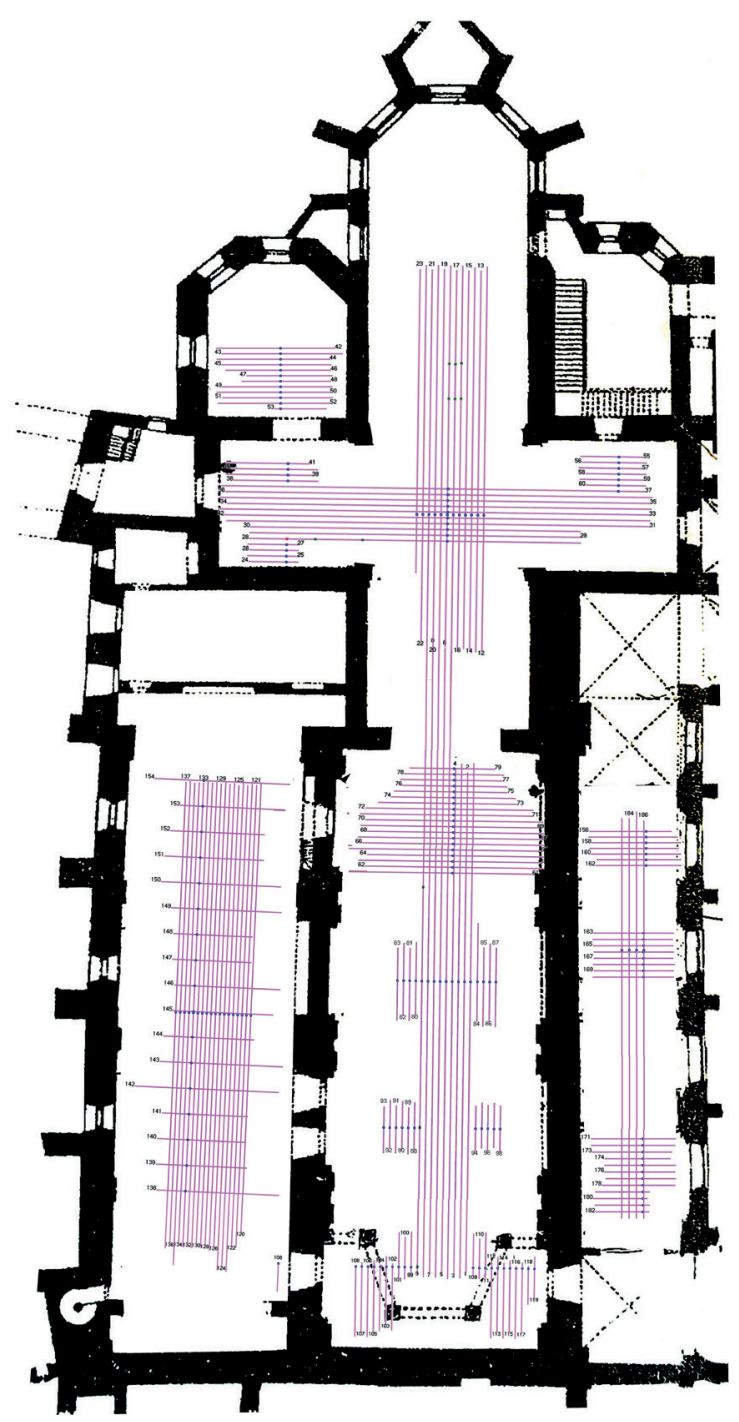

Fig. 3. Krakow, St. Francis' of Assisi Basilica; location of georadar profiles using MalaGX georadar, affixed on archival church's sketch (developed by Geo-radar Company 2015)

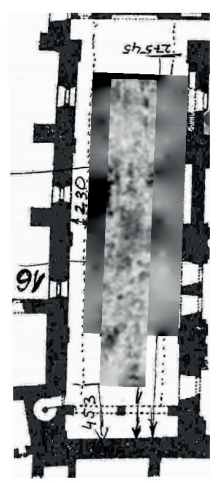

$-32 \mathrm{~cm}$

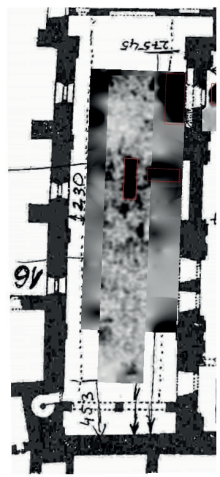

$-56 \mathrm{~cm}$

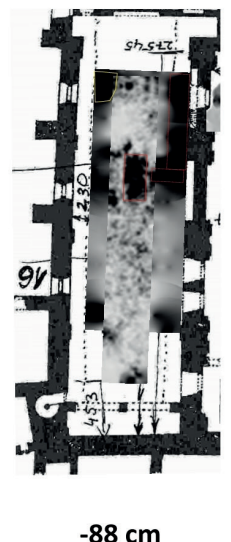

$-88 \mathrm{~cm}$

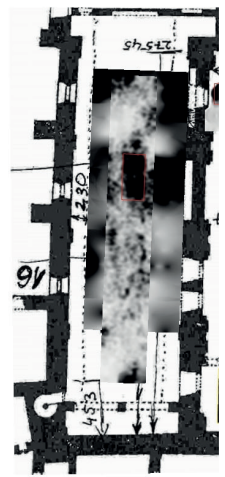

$-120 \mathrm{~cm}$

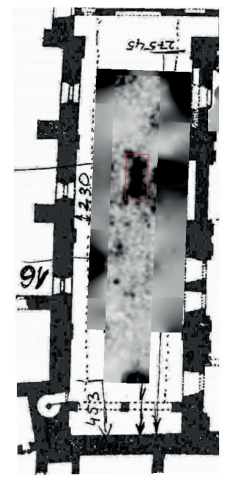

$-152 \mathrm{~cm}$

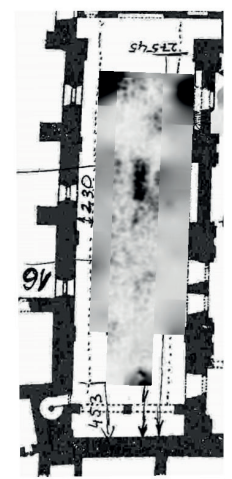

$-200 \mathrm{~cm}$

Fig. 4. Krakow, St. Francis' of Assisi Basilica; location of georadar anomalies recorded at various depths under the floor surface made by georadar MalaEX affixed on the Chapel of the Passion sketch (developed Geo-radar Company 2015) 
Anomalies presented on individual sections show these contrasts in the studied medium, which give a response to an electromagnetic wave of a given frequency. In the applied visualization method using horizontal slices, the object of visualization is the absolute amplitude of the georadar response. Increased absolute amplitude of the signal (dark areas, Fig. 5) can therefore show both emptiness (framed in red; doubtful emptiness or those which location is difficult to identify undoubtedly were marked with dotted lines), as well as walls (or possibly massive clusters of debris - marked in yellow) (Fig. 5).

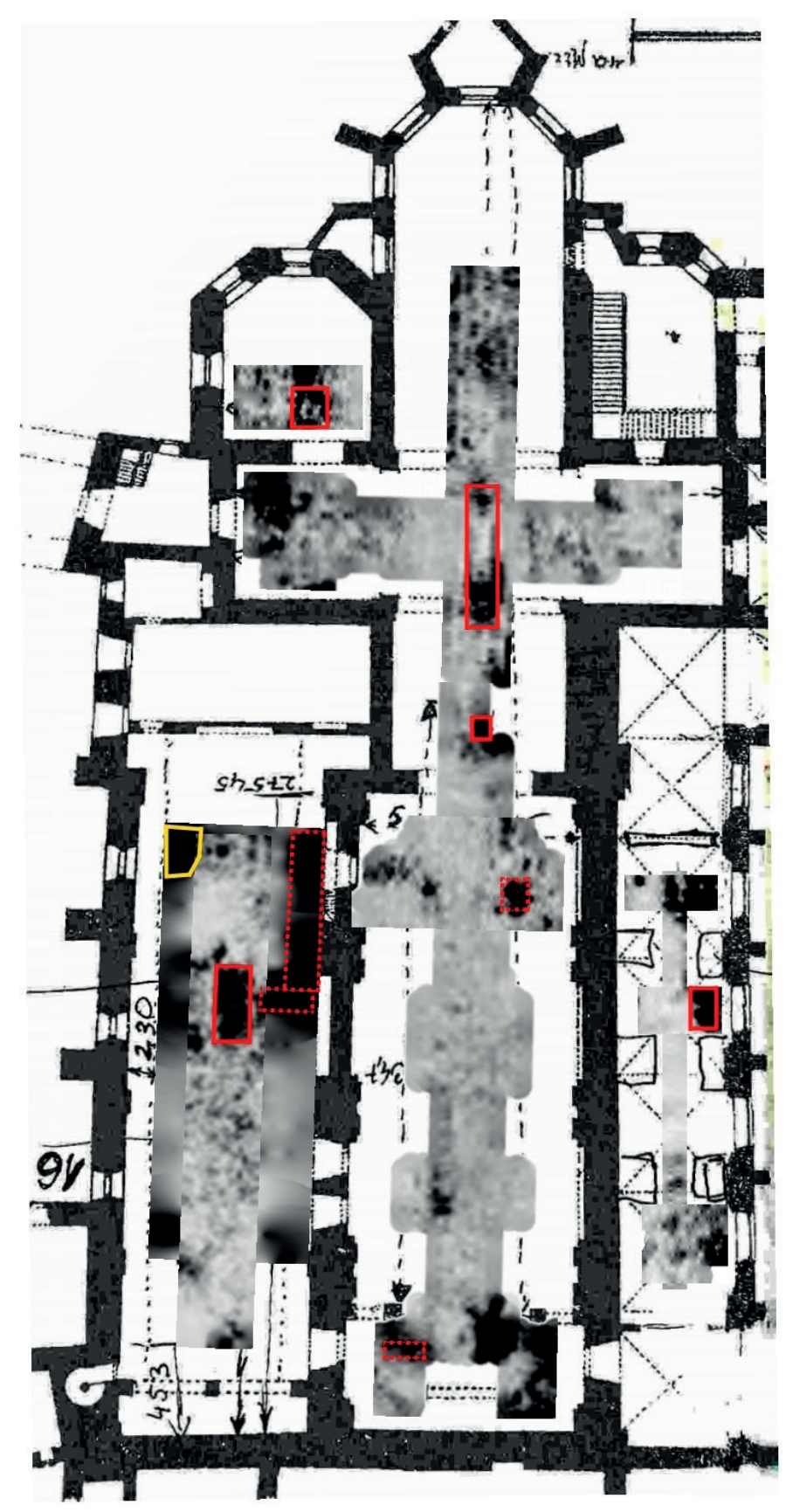

Fig. 5. Krakow, St. Francis' of Assisi Basilica; location of georadar anomalies at depth of around $88 \mathrm{~cm}$ under the floor surface made by georadar MalaEX affixed on the church's sketch; red colour - alleged and confirmed caverns (crypts, tombs), yellow colour - probable areas of over-compacted material concentration (bulworks, rubbles) (developed Geo-radar Company 2015) 
Recognition using the $300 \mathrm{MHz}$ VIY 3-300 antenna covered the Chapel of the Passion. Data acquisition was carried out on the six profiles (Fig. 6). During the acquisition, the following settings were applied: survey step every $26.03 \mathrm{~mm}$ (step of collecting scans before stacking), stacking level 8, sampling frequency of 500 (samples/scan), time window of $166 \mathrm{~ns}$. Recorded raw data from the survey area has been processed using dedicated software.

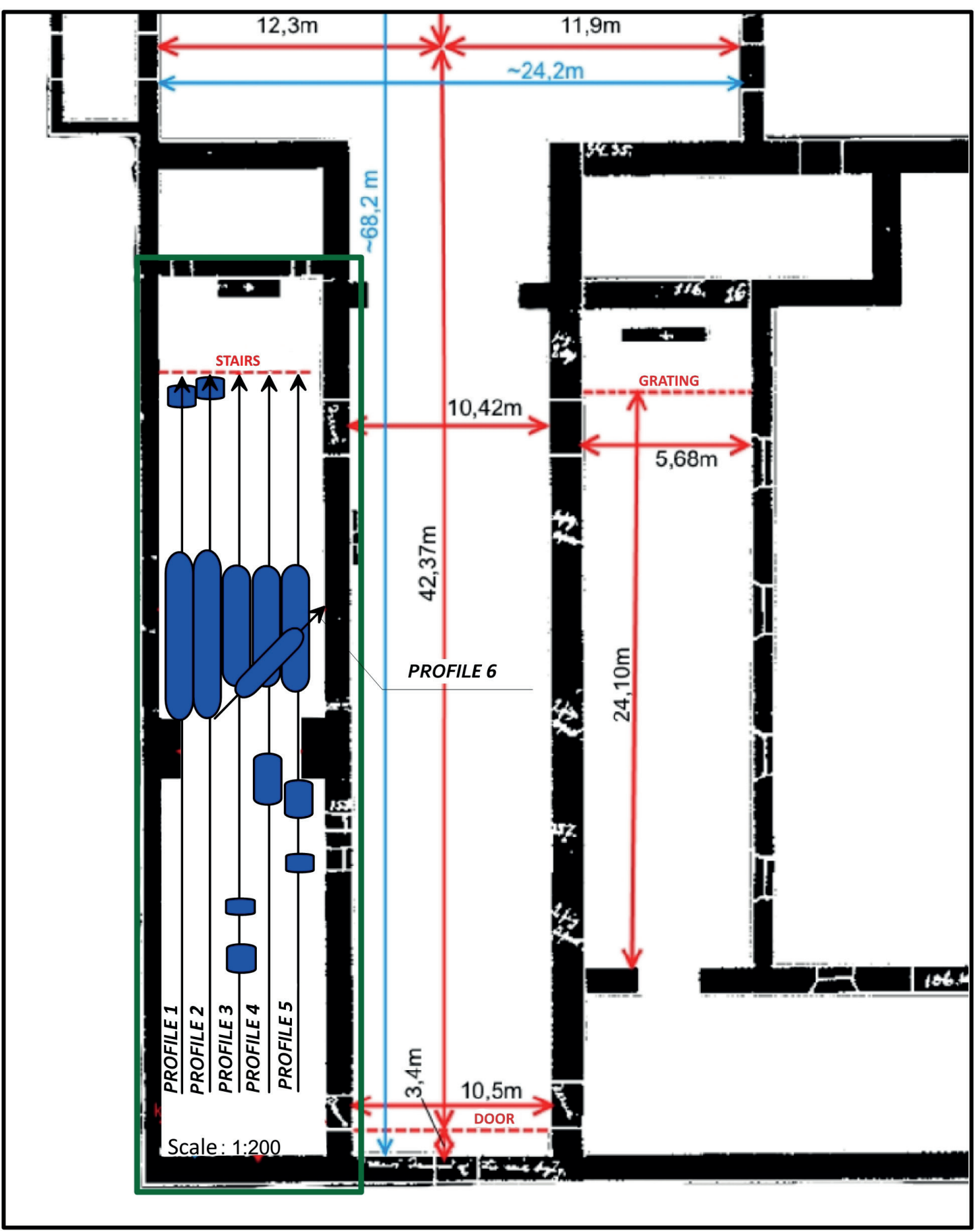

Fig. 6. Krakow, St. Francis' of Assisi Basilica; positions of georadar anomalies (blue stripes) marked on the situation map of the area recorded by VIY3-300 equipment in Chapel of the Passion (developed by J. Adamiec and T. Skupień 2015) 
The first step was to remove the high frequency noise, then applied Background Removal (it removes the average route from each profile route), then averaging was used, the strengthening according to the linear characteristic, the three-point equalizer (multifunctional tool with two modes: [1] sharpening the boundaries and increasing the spatial resolution of the GPR profile, [2] smoothing tracks and suppressing periodic oscillations of any shape) and a wavelet filter (performing crosscorrelation of the trace with "Mechican Hat" function, to suppresses low frequency fluctuations and high frequency noise). Finally, the signal was transformed from the time domain into the depth domain. The time-depth conversion was done using the velocity estimated on the basis of the fitting of the model hyperbole. The registered anomalies were marked on the situational map (Fig. 6).

\section{CRYPT IDENTIFICATION BY THE USE OF GPR}

As mentioned above, one of the main goals of the reconnaissance was to locate underground rooms; so the characteristic architectural features of the crypts play a crucial role during the final analysis of the GPR signals obtained. By the notion crypt is meant a vaulted room or a sequence of such rooms, connected with each other and the space of the church with a system of vaulted corridors, passages, stairs; such systems could be inside or partly outside the church, and could be partially or completely embedded in the ground. Functionally they originally played the reliquary role, sometimes also the oratorio (lat.) and sepulchral role (Graczyńska 2004).

The beginnings of the development of the funeral crypt reach the ancient confessio (lat.), that is, the burial chamber with the body of a saint or martyr, located under the main altar of the early Christian church (Latin confessio, e.g. St. Emmeram's church in Regensburg), which during the formation of Carolingian architecture, and then Ottonian one, developed into the form of a hall crypt (i.e. the monastery church in Fulda, the church of St. George on the island Reichenau in Oberzell, the cathedral in Essen) and the tunnel crypt (basilica of Einhard in Steinbach). Such rooms were usually located under the presbytery that was raised above the floor level and constituted an important element of the spatial program of the temple, as containing the grave or relics of the saint. Further development of the hall crypt, based by two (or more) rows of columns (canopies crypt), covered with a cross vault and sometimes located not only exclusively under the presbytery, but also under the transept, or even under the part of the central nave or under the western choir, occurred during the formation of Romanesque architecture period (cathedral in Gurk "one hundred columns crypt", Wawel's cathedral in Cracow - crypt of St. Leonard) (Koch 1996, Graczyńska 2004). With time, the adoration of the saint's relics was moved to separate, specially designed chapels (the so-called chevet), thus the representative rooms under the presbytery lost their raison d'être. In later centuries crypts as small underground rooms became a places of burial of famous personalities; initially their location was marked on the floor's surface with tombstones/epitaphs, however, over time, due to flooring changes, renovations or alterations of churches, their actual location could be blurred or even completely forgotten.

In this context each anomaly, recorded in St. Francis of Assisi Basilica, was analyzed for the occurrence of barrel vaults on $2 \mathrm{D}$ echograms showing vertical cross-sections (Fig. 7). This is the simplest and fastest way to confirm the existence of the crypt. Such objects of a sepulchral character in the former European sacred building have, as a rule, a barrel vault, or less often, a basket vault. Signals corresponding to the shape of such a ceiling accompanied below by the reflections from the room's floor or from objects possibly filling its interior are the basic diagnostic signs of the crypt's presence that have high effectiveness of identification. Most often they are accompanied by slightly weaker scattered signals from the junctions of walls with vaults and walls with the floor. Other irregular forms of scattering signals that do not suggest the presence of the above mentioned architectural elements of the proper crypt are considered to be signs of dubious rooms or rubble spaces - without distinction whether it is a cluster of rubble material (i.e. in the form of a destroyed foundation wall of a non-existent architectural object) or collapsed (filled with rubble) crypt. 


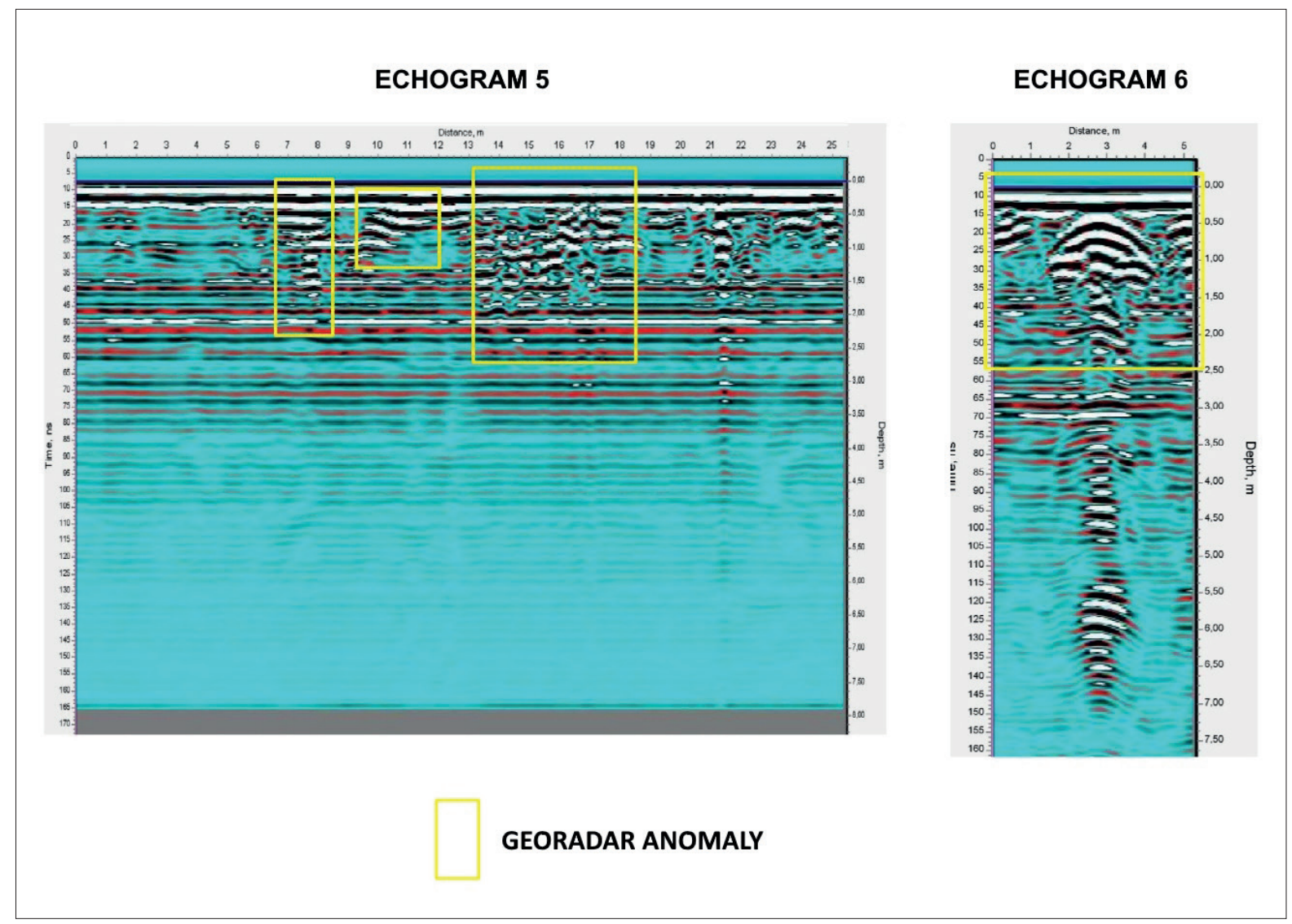

Fig. 7. Krakow, St. Francis' of Assisi Basilica; georadar echograms showing anomalies recorded along profiles 5 and 6 by VIY3-300 antenna in Chapel of the Passion; the crossing point of the two profiles is located at distance $3 \mathrm{~m}$ on the profile 6 and at distance $15.5 \mathrm{~m}$ on the profile 5, inside area of a distinctive GPR anomaly (developed by J. Adamiec and T. Skupień 2015)

In this method, any anomaly bearing the distinctive features of a vaulted underground room (or dubious anomaly) is treated as a hypothesis regarding the probable presence of a room or other object in a given place, which can be verified by means of direct research methods.

\section{DISCUSSION OF THE SURVEY RESULTS}

Based on the GPR surveys, numerous anomalies in georadar response of the ground have been found, which indicate both the presence of voids (interpreted as grave crypts, individual graves or possibly unknown elements of infrastructure e.g. old ventilation ducts), and concentrations of high-permittivity compacted materials in the substrate (which may indicate for the presence of architectural relics, concentration of debris, as well as older utility levels - stone or brick floors).
The comparison of these results with the archival plan of the church, on which tombstones known at the beginning of the $20^{\text {th }}$ century were marked (perhaps at that time still distinguished in the floor surface, cf. Fig. 8), enabled the immediate recognition of underground rooms not yet registered in available archival cartographic materials (Karwacki 1908). Profile echograms (vertical cross-sections, Figs. 9, 10) show clear manifestations of all the previously mentioned typical architectural elements of the rooms, including, above all, a clear outline of the curvature of the vaults. A detailed analysis of echograms allows also to make far-reaching conclusions as to the detailed location of crypt walls, the depth of rooms or the distance of the vault from the contemporary floor. Such previously unknown rooms were located in the central and south-eastern part of the Chapel of the Passion (Fig. 11). 


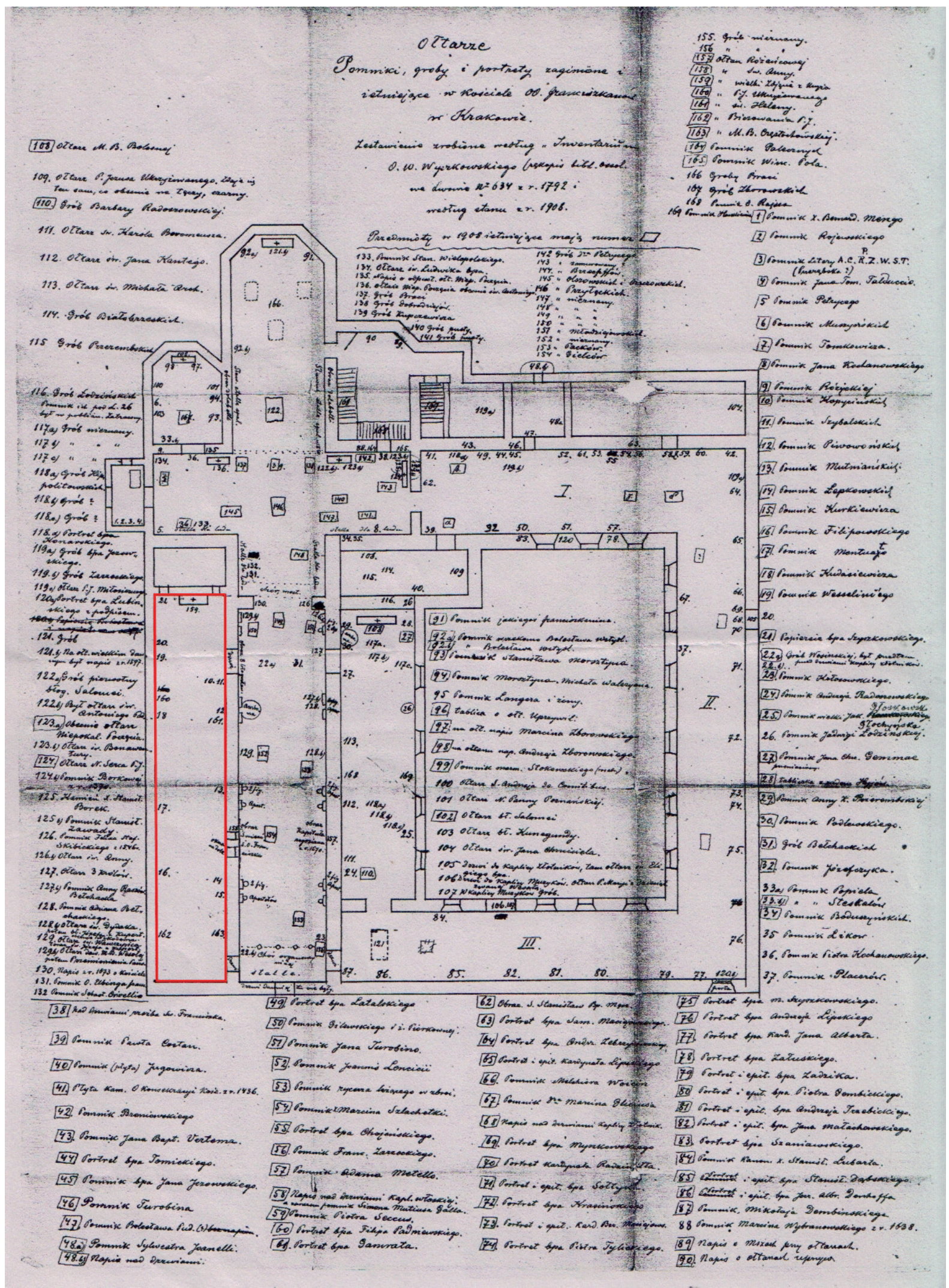

Fig. 8. Krakow, St. Francis' of Assisi Basilica; the archival document (Karwacki 1908), containing an inventory of St Francis' of Assis Basilica (Krakow) like altars, monuments, tombs and portraits (missing and existing) in the Church; Chapel of the Passion - where the formerly unknown crypts were located - marked with red colour 


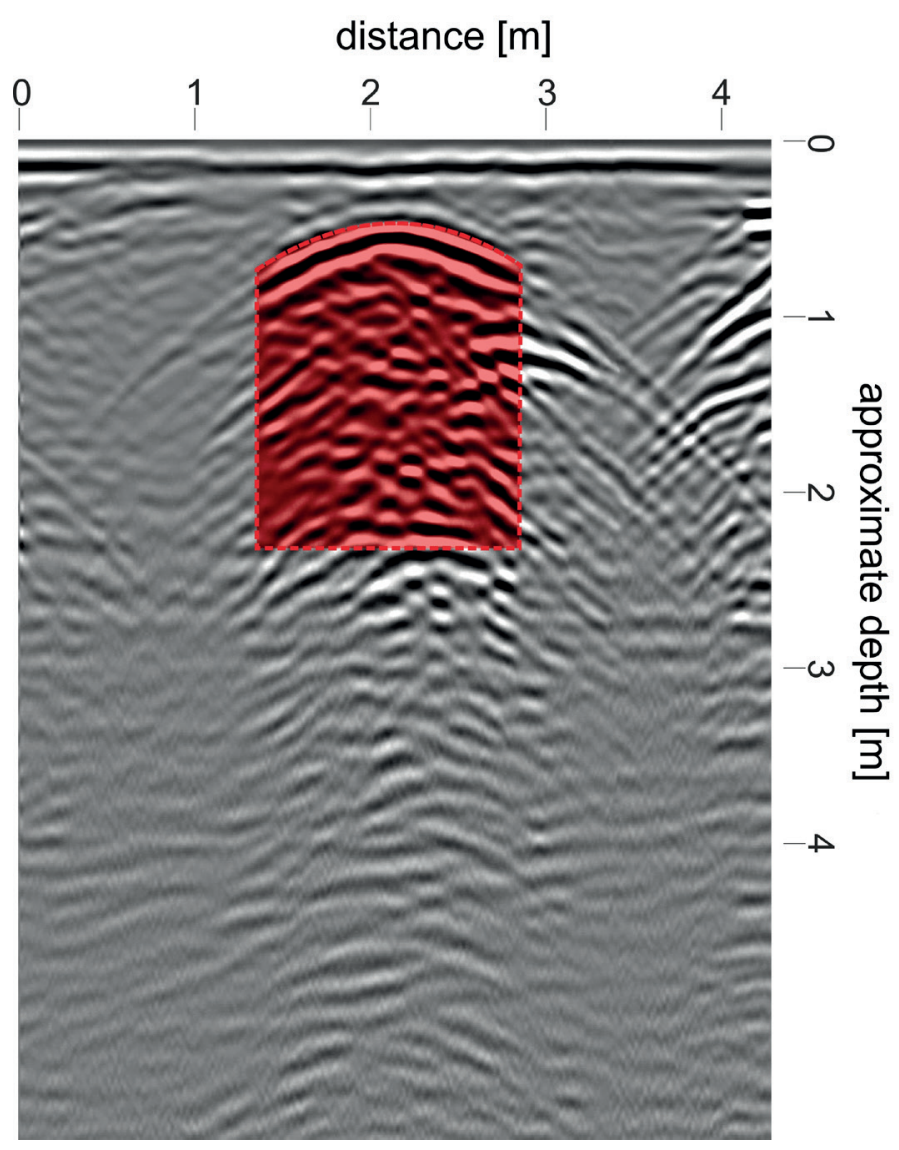

Fig. 9. Krakow, St. Francis' of Assisi Basilica; georadar profile (no. 147 from Figure 3; north-south direction) recorded by MalaGX equipment in the central part of Chapel of the Passion, showing the shape of a newly discovered crypt, echogram present rough, no filtered data (developed by Georadar Company 2015)

Transient Technologies LLC

distance, $m$

Transient Technologies

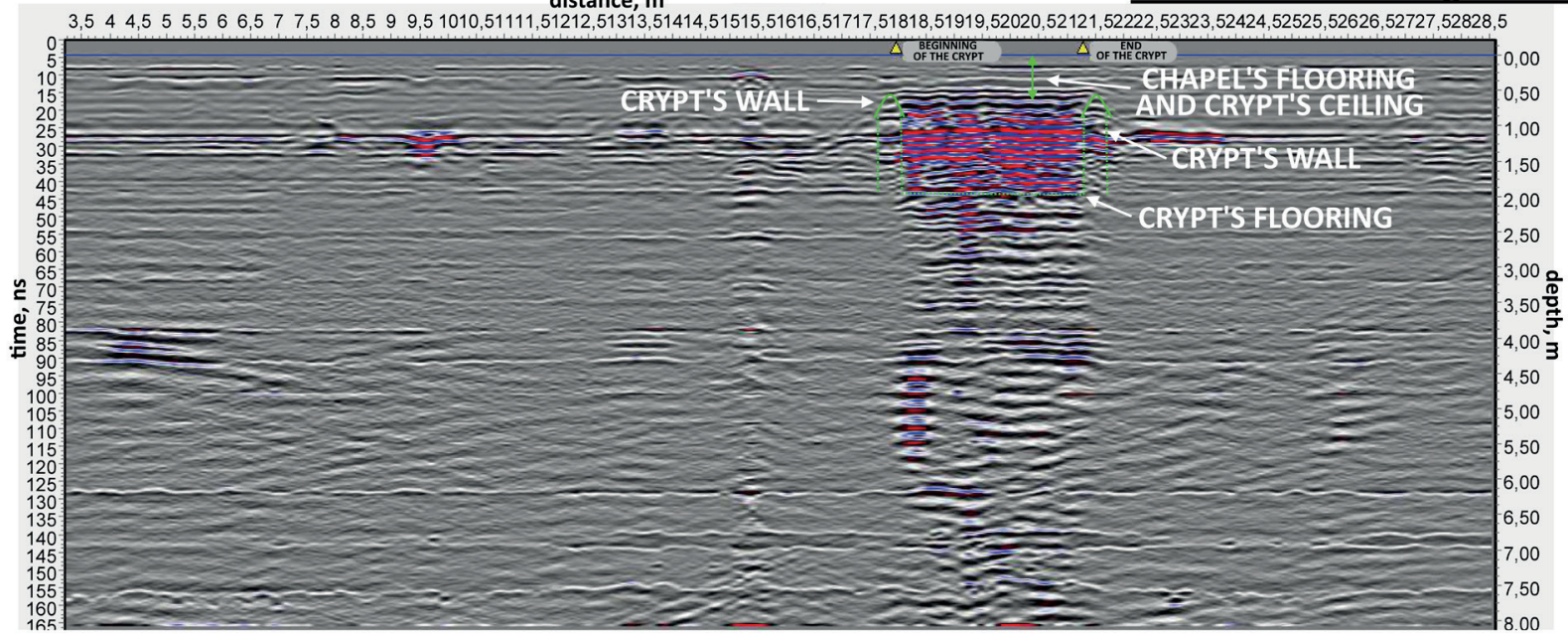

Fig. 10. Krakow, St. Francis' of Assisi Basilica; georadar profile (no. 3 from Figure 6; west-east direction) recorded by VIY3-300 equipment in the central part of Chapel of the Passion, showing the shape and characterisic features of a newly discovered crypt (developed by J. Adamiec and T. Skupień 2015) 


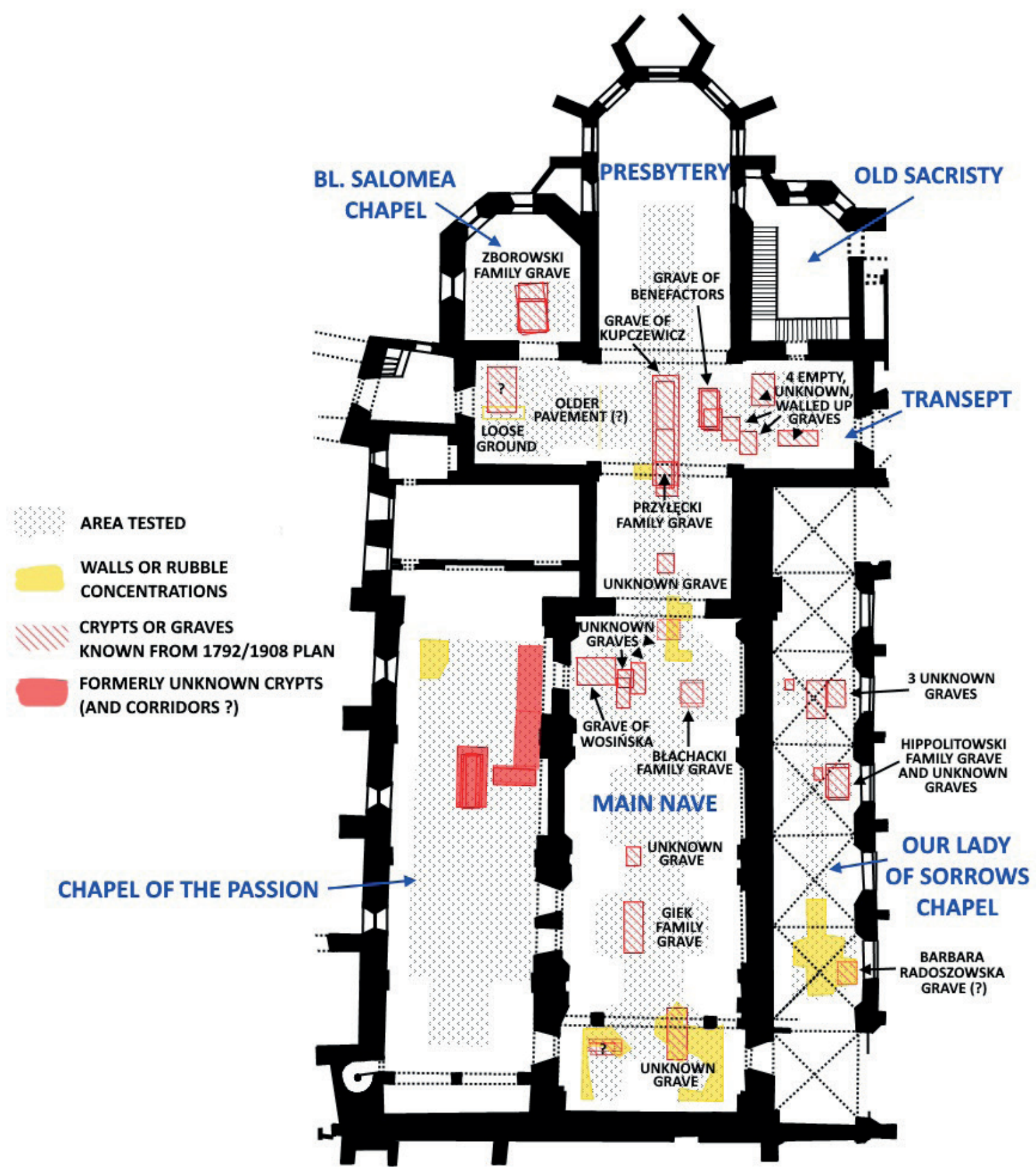

Fig. 11. Krakow, St. Francis' of Assisi Basilica; location of the georadar anomalies recorded by MalaGX equipment marked on the church's sketch with initial attribution of the graves, prepared on the basis of an archival sketch from the years 1792-1908; the expression "unknown thumb" is used for objects that were unidentified in beginning of the $20^{\text {th }}$ century, despite their location was known earlier (developed by M. Eyczak 2016 - based on a report made by Geo-radar Company)

In order to verify the data from georadar surveys (after completion of the non-invasive diagnosis), two small-diameter holes were drilled in the chapel's flooring through which an endoscopic camera was inserted into the rooms. Observations of the obtained film material confirmed that the structural image recorded by both antennas is a manifestation of the presence of a vaulted brick 
crypt located on the axis of the chapel (its ceiling was drilled at a depth of $80-85 \mathrm{~cm}$ ) and an elongated, brick crypt or corridor in its south-eastern part. The arrangement of both rooms does not rule out that they may potentially be connected by an existing or walled up entrance. This hypothesis would, however, require verification by invasive archaeological and architectural research.

In both crypts there are several or even a dozen pieces of wooden coffins, crowded but relatively well preserved (Fig. 12). Originally, they probably had textile or leather upholstery, as evidenced by the presence of metal fastening studs on their surfaces. At least at one of the coffins a monogram made of studs is also visible.

It is initially assumed that burials from both crypts were made in modern times, probably in the $17^{\text {th }}-18^{\text {th }}$ centuries. Good condition and completeness of coffins suggest that there are still intact bodies with grave equipment inside.

Probably the greater part of the burials is in the original place of entombment. However, the presence of small amounts of brick debris in the crypts may also suggest that the crypts were violated, for example, during one of the church fires. Some coffins may also be moved there from their original assembly sites. It is also not excluded that the discovered crypt can be identified with the private tomb, mentioned in historical sources, made by the custodian of the Franciscan Order for a private person in 1612 (AFK, AK-XI a-2, page 5); it has been done without the consent of the Archconfraternity of the Christ's Passion (Good Death), which kept this part of the temple in disposal. This tomb, colliding with the previously planned friars' grave, as mentioned in those papers, is located "in the middle of the chapel". The same source also mentions the presence of older graves in the chapel (Rojkowska-Tasak \& Dettloff 2015). However, any attempt to verify these hypotheses would require systematic archaeological excavations.

In order to verify the interpretations of georadar data, a hole was also drilled in the Chapel of Blessed Salomea (Fig. 13). Likewise the previous also this hole showed the presence of a burial crypt with coffin burials, identified as a crypt of the Zborowski family.

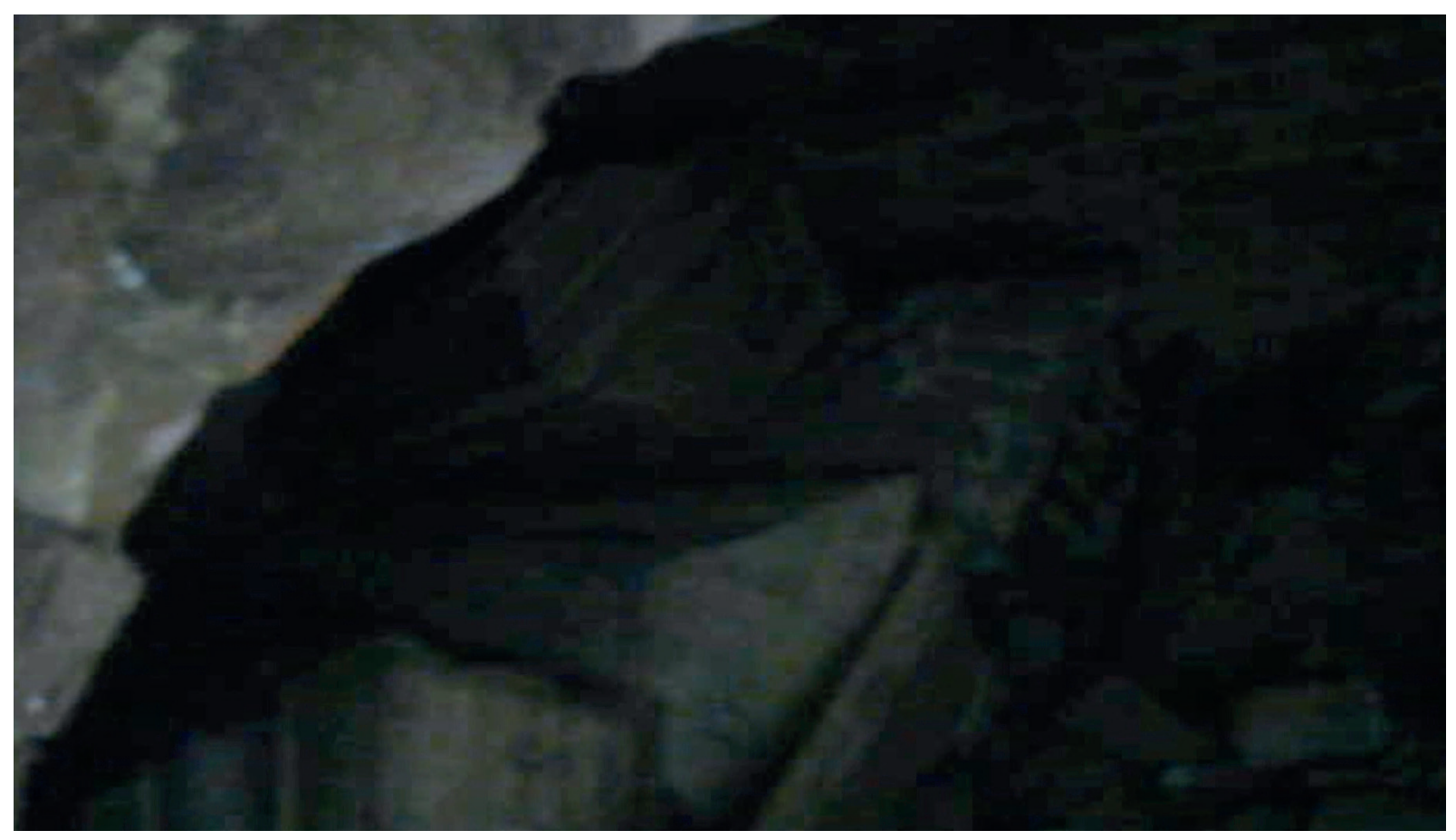

Fig. 12. Krakow, St. Francis' of Assisi Basilica, Chapel of the Passion; the interior of the crypt located in the central part of the chapel - coffins visible (one with a graphic monogram) (photo SAKWA Society 2015) 


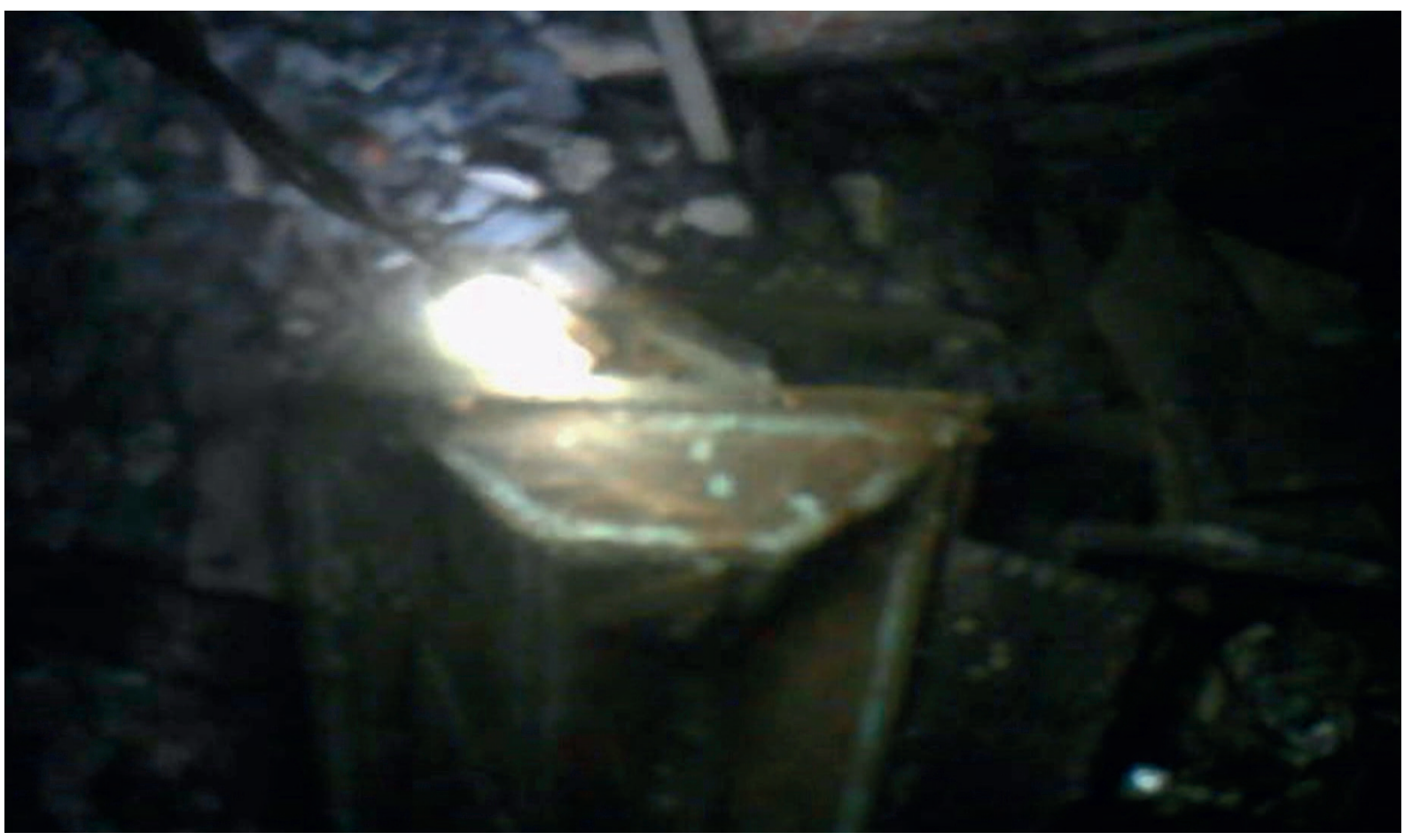

Fig. 13. Krakow, St. Francis' of Assisi Basilica, Blessed Salomea Chapel; the interior of the crypt located in the central part of the chapel - coffins decorated with metal studs (photo SAKWA Society 2015)

\section{CONCLUSIONS}

The georadar survey of the Krakow St. Francis church's flooring brought measurable effects on the historical spatial development of the sanctuary.

First of all, the credibility of the archival plan with the distribution (and attribution) of individual crypts and graves was confirmed, detailing the actual location and sizes of the objects, which were only schematically marked on this plan.

Furthermore, presence of some beforehand unknown lodgings was recognized. They may potentially build small interior complex (for instance in the form of crypts linked by passages). The hypothesis could be verified by additional georadar survey inside the room behind the Passion of Jesus Chapel (inaccessible during the survey) or through archaeological excavations made in the discovered passage near the chapel's altar.

As the result of presented survey, in 2017 a three-year research project "The burial crypts of the Church. St. Francis of Assisi in the light of interdisciplinary research" was started. It is led by prof. dr hab. Anna Drążkowska from the University of Nicolaus Copernicus in Torun and financed by the National Science Center. Its basic purpose is a comprehensive research analysis of underground rooms registered with non-invasive methods. Nevertheless, during fieldwork, also the obtained results of the GPR tests will be verified, which will allow to improve interpretations of echograms obtained during research.

Geophysical methods have been commonly used in both engineering and research works for many years. It is worth to remember to use the right methods for a specific purpose. These methods enable a non-invasive identification of the structure of the medium, its parameters and anomalies occurring in it, in a continuous, economical and fast way. Thus, they allow to optimize the distribution of future test drills or reconnaissance trenches.

Particularly important for the reconstruction of building changes in the area occupied by the St. Francis Church is capturing several places where one can potentially expect relics of older 
buildings. Their location on the generated plans will allow a rational planning for possible future archaeological and architectural research.

\section{REFERENCES}

AFK - Archiwum Prowincji oo. Franciszkanów W Krakowie, SYGN. AK-XI a-2: Acta Archiconfraternitatis Compassionis Jesu Christi et Beatissimae Virginis Mariae, in Ecclesia P. Francisci Ord. Min. Convent. ab Illustissimo et Renerendissimo Domino, D. Martino Szyszkowski, Episcopo Cracovien. Senesien. Fundatae. Renovata atque in pristinum ordinem cura et studio D. Alberti Zyzowicz, eiusdem Archiconfraternitatis notariii reducta, sub Prefectura Adm. Rndi Patris P. Francisci Wierzbicki, Guardiani et regentis Conventus. Anno Domini 1646 die Septembris, t. I [1611-1688].

Bochnak A. \& Samek J. (red.), 1971. Katalog zabytków sztuki $w$ Polsce. T. 4, Miasto Kraków. Cz. 2, Kościoły i klasztory Sródmieścia, 1. [Vol. 3]. Wydawnictwa Artystyczne i Filmowe, Warszawa.

Conyers L.B., 2004. Ground-Penetrating Radar for Archaeology. AltaMira Press, Walnut Creek, CA.

Graczyńska M., 2004. Krypta w dobie pierwszych Piastów typologia i geneza formalno-stylowa. [in:] Janiak T. \& Stryniak D., Poczatki architektury monumentalnej w Polsce: materiaty z sesji naukowej, Gniezno, 20-21 listopada 2003 roku, Muzeum Początków Państwa Polskiego, Gniezno, 363-372.

Jol H.M. (red.), 2009. Ground Penetrating Radar: Theory and Applications. Oxford.

Karczewski J., 2007. Zarys metody georadarowej. Uczelniane Wydawnictwa Naukowo-Dydaktyczne AGH, Kraków.

Karwacki A. OFMConv., 1908. Ottarze, Pomniki, groby i portrety zaginione i istniejace w Kościele oo. franciszkanów w Krakowie. Zestawienie zrobione wedtug „Inventarium o. W. Wyszkowskiego" (rękopis bibl. ossol. we Lwowie no. $634 z$ r. 1792 i wedtug stanu $z$ r. 1908 [sketch from the Monastery of the Franciscan Order's archives].

Kęder I. \& Komorowski W. (red.), 2007. Ikonografia placu Wszystkich Świętych oraz ulic Franciszkańskiej, Poselskiej, Senackiej i Kanoniczej w Krakowie. Katalog Widoków Krakowa, 4, Towarzystwo Autorów i Wydawców Prac Naukowych Universitas, Kraków.

Koch W., 1996. Style $w$ architekturze: arcydzieła budownictwa europejskiego od antyku po czasy wspótczesne. Świat Książki, Warszawa.

Łyczak M., 2015. Sprawozdanie z badań poszukiwawczych na terenie kościoła św. Franciszka i klasztoru oo. Franciszkanów w Krakowie [typescript in the archive of Wojewódzki Urząd Ochrony Zabytków (WUOZ) in Krakow].

Łyczak M., 2016. Wyniki badań i nadzorów archeologicznych przeprowadzonych w latach 2011-2015 na terenie klasztoru oo. Franciszkanów w Krakowie [typescript in the archive of Wojewódzki Urząd Ochrony Zabytków (WUOZ) in Kraków].

Łyczak M., Zaitz E. \& Zaitz M., in print. Lokalizacja klasztoru oo. Franciszkanów na tle układu urbanistycznego średniowiecznego Krakowa. [in:] Szyma M. \& Walczak M. (red.), Sztuka w kręgu krakowskich franciszkanów i klarysek, Kraków.
Niewalda W., 2004. Okółkrakowski:problemy badawcze ikonserwatorskie. Wydział Architektury Politechniki Krakowskiej im. Tadeusza Kościuszki, Kraków [Ph.D. dissertation under the supervision of prof. dr hab. eng. arch. B.M. Pawlicki].

Niewalda W., 2006. Klasztor oo. Franciszkanów w Krakowie; nadzór architektoniczno-badawczy przy wykopach archeologicznych $w$ rejonie parkingu [typescript in the archive of Wojewódzki Urząd Ochrony Zabytków (WUOZ) in Kraków].

Niewalda W. \& Krasnowolski B., 1981. Układy urbanistyczne Okołu - próba rekonstrukcji. Teka Komisji Urbanistyki i Architektury, 15, 69-82.

Niewalda W. \& Rojkowska H., 2006. Zespół klasztorny Franciszkanów w Krakowie - relikty z XIII wieku. [in:] Kliś Z. (red.), Studia z dziejów kościoła Franciszkanów w Krakowie, Polskie Towarzystwo Teologiczne. Sekcja Wydawnicza Wydawnictwo Unum, Kraków, 81-130.

Niewalda W. \& Rojkowska H., 2008. Średniowieczny kościół franciszkanów w świetle ostatnich badań. [in:] Ożóg K., Gałuszka T. \& Zajchowska A. (red.), Mendykanci w średniowiecznym Krakowie, Wydawnictwo Esprit, Kraków, 271-298.

Radwański K., 1975. Kraków przedlokacyjny. Rozwój przestrzenny. PTAiN, Kraków.

Rojkowska-Tasak H. \& Dettloff P., 2015. Kaplica Męki Pańskiej bazyliki św. Franciszka z Asyżu przy klasztorze franciszkanów w Krakowie. Dokumentacja naukowo-historyczna, Kraków, [typescript in the authors' archive].

Skibiński Sz., 1977. Pierwotny kościół Franciszkanów w Krakowie. UAM, Poznań.

Szyma M., 2005. Relikty kamiennej budowli pod zachodnim skrzydłem klasztoru Franciszkanów w Krakowie. [in:] Gadomski J. (red.), Lapides Viventes: zaginiony Kraków wieków średnich: księga dedykowana profesor Klementynie Żurowskiej, Kraków, 149-157.

Walczak M., 2015. Kościoły gotyckie w Polsce. Wydawnictwo Uniwersytetu Jagiellońskiego, Kraków.

Włodarek A. \& Węcławowicz T., 2006. Architektura krakowskiego kościoła Franciszkanów XIII wieku: problemy i hipotezy badawcze: proponowane rekonstrukcje. [in:] Kliś Z. (red.), Studia z dziejów kościoła Franciszkanów w Krakowie, Polskie Towarzystwo Teologiczne. Sekcja Wydawnicza Wydawnictwo Unum, Kraków, 45-80.

Wyrozumski J., 1992. Kraków do schyłku wieków średnich. Dzieje Krakowa, 1, Wydawnictwo Literackie, Kraków.

Zaitz E., 2005. Plac Wszystkich Świętych 5. Klasztor oo. Franciszkanów, rejon Wyższego Seminarium Duchownego. Badania archeologiczne $w$ południowo-zachodniej części zabudowań klasztoru oo. Franciszkanów [typescript in the archive of Wojewódzki Urząd Ochrony Zabytków (WUOZ) in Kraków].

Zaitz E., 2006. Kraków - Stare Miasto. Plac Wszystkich Świętych 5. Klasztor oo. Franciszkanów, planowana budowa nowego skrzydła biblioteki. Sondażowe badania archeologiczne w 2006 roku [typescript in the archive of Wojewódzki Urząd Ochrony Zabytków (WUOZ) in Kraków].

Zaitz E., 2014. Kraków romański w świetle badań archeologicznych. [in:] Bochenek M. (red.), Kraków romański: materiały sesji naukowej odbytej 13 kwietnia 2013 roku, Towarzystwo Miłośników Historii i Zabytków Krakowa, Kraków, 55-84. 